\title{
Correction: Rapid and Localized Mechanical Stimulation and Adhesion Assay: TRPM7 Involvement in Calcium Signaling and Cell Adhesion
}

Wagner Shin Nishitani, Adriano Mesquita Alencar, Yingxiao Wang

In the Data Availability section, there is an error in the DOI for the data uploaded to the Harvard Dataverse Network. The correct DOI is 10.7910/DVN/O239GQ. The complete, correct Data Availability section should read as follows:

All files are available from the Harvard Dataverse Network (http://thedata.harvard.edu/ dvn/, doi: 10.7910/DVN/O239GQ).

\section{Reference}

1. Nishitani WS, Alencar AM, Wang Y (2015) Rapid and Localized Mechanical Stimulation and Adhesion Assay: TRPM7 Involvement in Calcium Signaling and Cell Adhesion. PLoS ONE 10(5): e0126440. doi:10.1371/journal.pone.0126440 PMID: 25946314

f open ACcess

Citation: Nishitani WS, Alencar AM, Wang Y (2015) Correction: Rapid and Localized Mechanical Stimulation and Adhesion Assay: TRPM7 Involvement in Calcium Signaling and Cell Adhesion. PLOS ONE 10(9): e0138281. doi:10.1371/journal. pone. 0138281

Published: September 14, 2015

Copyright: @ 2015 Nishitani et al. This is an open access article distributed under the terms of the Creative Commons Attribution License, which permits unrestricted use, distribution, and reproduction in any medium, provided the original author and source are credited. 